\title{
Relationship between emotional intelligence, burnout and health perception in a sample of football Spanish referees \\ Relación entre inteligencia emocional, burnout y percepción subjetiva de salud en árbitros españoles de fútbol
}

\author{
Xavier Estrada Fernández, María Priego-Ojeda, Agnès Ros Morente, Carles Alsinet Mora
}

Universidad de Lérida (España)

\begin{abstract}
Football referees must undergo unique physical, tactical and psychological preparation to face the demands of the game and perform efficiently. Psychological factors, particularly emotional intelligence, are directly linked to sports performance, but it is also affected by other variables such as health and burnout. The objective of this study is focused on evaluating emotional intelligence and its relationship with subjective perceptions of health and burnout syndrome in Spanish football referees. Participants in the study were 4099 referees from all categories in Spain between the ages of 14 and 66 years, of which 3773 were men and 362 women. Three instruments were used: theTrait-Meta Mood Scale (TMMS-24), the 12-item General Health Questionnaire (GHQ-12) and the Oldenburg burnout inventory (OLBI). The results of the study reveal that the clarity and emotional repair dimensions of the emotional intelligence construct are inextricably connected with subjective perceptions of health, and, furthermore, that burnout acts as a mediating variable when it comes to a better perception of health. The results highlight the importance of working on psychological variables to foster better performance and the need to promote training programs to ensure efficient emotional management, eliminating disconnection and/or exhaustion syndrome that affects referee health.
\end{abstract}

Keywords: soccer, referee, emotional intelligence, health, burnout, education.

Resumen. Los árbitros de futbol requieren de una singular preparación física, táctica y psicológica para hacer frente a las exigencias del partido y realizar una eficiente actuación. Los factores psicológicos y en particular la inteligencia emocional está directamente implicada en el rendimiento deportivo, pero también, está relacionada con otras variables como la salud y el burnout. El objetivo de este estudio se ha centrado en evaluar la inteligencia emocional y su relación con la percepción subjetiva de salud y el síndrome de burnout en árbitros de fútbol españoles. Los participantes del estudio fueron 4099 árbitros españoles de todas las categorías entre 14 y 66 años, de los cuales 3773 fueron hombres y 326 mujeres. Se utilizaron tres instrumentos: el Trait-Meta Mood Scale (TMMS-24), el General Health Questionnaire-12 (GHQ-12) y el Oldenburg burnout inventory (OLBI). Los resultados del estudio muestran que las dimensiones claridad y reparación emocional del constructo de inteligencia emocional están relacionada directamente con la percepción subjetiva de salud, y, además, el burnout actúa como variable mediadora frente una mejor percepción de salud. Los resultados destacan la importancia de entrenar las variables psicológicas para promover un mejor rendimiento y la necesidad de promover programas formativos para una eficiente gestión emocional y prevenir el síndrome por desconexión y/o agotamiento que afecta a la salud de los árbitros.

Palabras clave: fútbol, árbitro, inteligencia emocional, salud, burnout, educación.

\section{Introduction}

In recent years, there have been many studies (Recio, Feliz \& Elorza, 2021; Contessoto, Costa, Anversa \& Refundini, 2020) based on the sports field giving special attention to psychological aspects of athletes (Rutkowska \& Bergier, 2015). Football is one of the most popular and practised sports worldwide, and, as athletes, referees are part of it. The referee is an essential figure for the proper development of the

Fecha recepción: 14-10-21. Fecha de aceptación: 27-01-22

Xavier Estrada Fernandez

x.estrada@icloud.com competition, being responsible for enforcing regulations with impartiality and fairness (García, González \& Salinero, 2011).

Referees must perform well in order to make the right decisions (Patiño \& Cañadas, 2015) during the course of the match (Ferreira \& Brandao, 2012), and in unexpected situations (Ortega, Villamizar \& Ramos, 2014). To do so, the appropriate physical (Weston et al., 2012), as well as mental (Spitz et al., 2018) preparation is necessary to regulate the conduct and behaviours of the players (Castillo, Yanci, Cámara \& Weston, 2016). Different stressors can not only affect a referee's performance, but also tend to cause emotional strain. A referee must therefore possess optimal men- 
tal skills in order to manage such stressors, not allowing them to negatively influence the execution of his duties on the pitch (Samuel, Englerft, Zhang \& Basevitch, 2018).

Different psychological variables, such as anxiety (Castro, Zurita, Ramírez \& Ubago, 2020), burnout (Aguirre, Tristán, López, Tomás \& Zamarripa, 2016), emotional intelligence (Gallardo, Domínguez \& Gonzalez, 2019) and health (Acebes, Granado \& Marchena, 2020) are especially important for sports psychology since the athlete has to manage pressure effectively and adapt to a competitive sporting context (Selmi et al., 2018). Some of these studies show how the control of psychological factors impacts on the development of the athlete (Bennett \& Maynard, 2017; Rodríguez, Gómez \& Álvarez, 2017). An example is the observation (Englert, Zwemmer, Bertrams \& Oudejans, 2015), highlighting the importance of selfcontrol to lessen the effects of anxiety. Other investigations illustrated the influence of stress in poor decision-making in football referees (Soriano, Ramis, Torregrossa \& Cruz, 2018) and basketball referees (Anshel, Sutarso, Ekmekci \& Saraswati, 2014). Thus, the training of cognitive skills, self-control and emotional regulation (among other factors) can ensure better performance among athletes (Ong \& Griva, 2017).

A study (Cantón \& Checa, 2012) found a relationship between negative results and experiences of poorly regulated emotions while participating in sporting activities. Other study (Guillén \& Feltz, 2011) showed that refereeing errors during a match result in a loss of confidence, an increase in anxiety and stress levels as well as causing burnout.

The practice of performance sports positively affects the development of an athlete's emotional well-being taking into account emotional intelligence and not only physical fitness (Shami, Tare \& Taran, 2017). In contrast, (Fernández-Berrocal, Fava \& Sonino, 2016) a lack of emotional self-regulation can result in health-related problems such as high levels of stress or anxiety, and it could bring a premature end to a referee's career due to exhaustion, disconnection or deteriorating health (Castro et al., 2020).

\section{Emotional intelligence (EI)}

Salovey and Mayer (1990) introduced the concept of EI for control, management, and expression of emotions. For these authors, EI is the ability to process information about one's own emotions and those of others, facilitating the use of this information as a guide for appropriate thought and behaviour, and thereby adapting to the environment.

Many sports psychology studies have been interested in EI, in emotions and their relationship with sport (Latinjak, López \& Font, 2014) and physical activity (Ros, Moya, \& Garcés, 2013; Laborde \& Doseville, 2015) as determinant variables of performance. Other authors (Enns, Eldrigge, Montgomery \& González, 2018) indicate the need for athletes to handle stress and anxiety, specifying the acquisition and improvement of a greater number of skills to manage emotions. Emotional skills contribute to better concentration and control of situations; and authors (Pena \& Extremera, 2012) point out that emotionally intelligent people are capable of developing efficient strategies to regulate different emotional states according to different situations. Thus, regulating and managing emotions will be a crucial factor for improving an athlete's mental well-being (Geng, 2018; Narwal \& Sharma, 2018; Rodríguez, Correa, García \& Bozal, 2018). In this line, various instruments have been used to measure people's personal perception (Fernández-Berrocal, Extremera \& Ramos, 2004) regarding their emotional capacities, based on skill models (Salovey \& Mayer, 1990). This model takes into consideration emotion attention (the ability to feel and express feelings correctly), emotional clarity (an ability to correctly assess one's own emotional state), and emotional repair (regulating the various moods in an optimal way).

For these reasons, EI allows them to cope with any pressure situations that may come up as it will allow them to manage such circumstances in a responsible, productive and optimistic way and to resolve problems in the context in which they arise (Sánchez \& Breso, 2020).

Finally, different research also emphasizes that the influence of EI increases with age (Castro et al., 2020); and years of experience, reaching its peak at age forty (Bar-On, 1997).

\section{Burnout syndrome}

Sports in general, and professional ones in particular, entail high levels of stress and emotional exhaustion (Maslach \& Jackson, 1981), characterized by the intense physical, cognitive and emotional demands of high performance, all of which give rise to the occurrence of a phenomenon known as burnout syndrome. This syndrome manifests itself when people lack the skills 
or resources to cope with certain situations they experience, generating problems such as depression and anxiety. Some studies (Gorczynski, Coyle \& Gibson, 2017; Rice et al., 2016) show that elite athletes have an increased risk of suffering from mental health problems and experiencing depression and anxiety.

Some authors (Rivera, Segarra \& Valverde, 2018) consider burnout to be a process in which the individual is consumed by not being able to deal with stress caused in the workplace, which has a significant negative impact on one's self-perception, resulting in emotional harm as well as a deterioration of one's physical condition. Other authors (Gustafsson, Hancock \& Cote, 2014) describe it as a decrease in performance, a reduction in motivation and an abandonment of the sports career. The construct represents the aspects of stress (Maslach \& Jackson, 1998) determined by two dimensions, such as exhaustion - encompassing both intense physical tiredness and emotional exhaustion that weakens the ability to operate effectively - and disengagement, which involves reduced personal performance due to a tendency to self-evaluate negatively combined with a deep feeling of ineffectiveness carrying out the task itself and with others.

The vast majority of scientific studies published on the reference construct in the sporting context have focused on athletes, with fewer having concentrated on referees or sports judges (García, González \& Garcés, 2016; Pedrosa \& García, 2016). Nevertheless, a study (Pedrosa \& García, 2015) involving 123 members of the 1 st and 2nd division of the Spanish Professional Football League (Liga Nacional de Fútbol Profesional LFP), shows that the variables of stress, anxiety, and social support cause this group to be more affected by burnout syndrome. Within that group, 1st division referees, particularly those with more experience, are the ones who suffer the most. Another study (Sirin \& Dosylmaz, 2017) on football referees from the Turkish professional league draws similar conclusions, showing that the more years one has spent refereeing, the higher the levels of burnout.

In contrast, studies (Arbinaga, Fernández, Herrera \& Vela, 2019) on football and basketball referees, refute the idea that the most experienced athletes are those with the greatest emotional exhaustion. On the other hand, investigations (Bernardo, Macedo \& Álvarez, 2017) show that referees with less experience are the ones who experience the highest levels of burnout, although this also depends on career progress and the referee category achieved. In addition, another study (Jafarloo,
Keshavarz \& Bashiri, 2020) introduces the EI construct and its relationship with the decrease in burnout in female Iranian referees.

\section{Health perception}

The evaluation of well-being and psychological health is another variable to be considered. This is the case for both athletes in general and referees in particular, and is indeed a growing field of interest. In athletes, it is important to promote psychological health associated with the practice of physical activity and sport (Zazo \& Moreno, 2015), in order to enhance resources and quality of life. Such well-being is quantified in terms of a personal perception that life is developing satisfactorily, coupled with an awareness of one's personal development (Ryff \& Singer, 1998). A great deal of research has shown the validity of this construct as a means of evaluating the satisfactory conditions for perceiving personal well-being (Reigal, Videra, Parra \& Juárez, 2012) and also in how that relates to performance sports (Carrasco, Campbell, López, Poblete \& García, 2013).

The perception of health is a significant construct in a self-assessment of quality of life, because the interpretation that is made of one's own health does not always correspond to its real state, thereby conditioning the perceived degree of well-being. When we speak of psychological well-being, we consider the perception of general health that has been explored in both physical activity and sport (Hamer, Stamatakis \& Steptoe, 2009). Psychological well-being is the result of leading an appropriate lifestyle, while being aware of the development of one's potentialities (eudaimonic or psychological well-being; Ryff \& Singer, 1998), as opposed to hedonic or subjective well-being (Keyes, Shmotkin \& Ryff, 2002).

Some authors (Hamer et al., 2009) state that there is a direct relationship between the practice of physical activity and a lower perception of physical and mental health problems. Similarly, a correlation is found to exist between satisfactory physical condition and selfperceived good health (Mota et al., 2012).

Refereeing, as a task carried out in a competitive sport such as football, requires, among other things, management of stressful situations that derive from decision-making. Some studies (Salom et al., 2021) suggest that personal resources (Olivares, 2020) act as mediators of stress as a risk factor when it comes to mental and physical health. 


\section{Objectives}

Taking all the above into account, this work aims to study the relationship between the EI of football referees with subjective perceptions of health. In addition, it intends to analyse the connection of burnout syndrome with these two constructs. Finally, it is considered necessary to investigate the relationship between a set of variables such as category, age, and years of experience of the referees with different dimensions of the constructs of burnout syndrome, EI and health.

The present study aims the following objectives: (1) to observe differences in the explored variables when it comes to the referees' years of experience, their category, and age groups in relationship with EI dimension, burnout, and perception of health; (2) to explore how the different dimensions of EI influence the subjective perception of health, observing the type of relationship (linear, quadratic, etc.); (3) to analyse how these dimensions act as a protective factor against burnout. (4) To examine the possible moderating role of the different dimensions of EI with regard to the relationship established between burnout and the perception of health; (5) and ultimately, to affirm that health perception is affected by burnout and that this could present a mediating role between EI and the perception of health.

The hypotheses of the present study suggest that the dimensions of EI are directly related to a referee's subjective perception of their health. Additionally, the dimensions of burnout syndrome could be an explanatory factor in subjective perception of health, thereby acquiring a mediating role between the two.

For the EI construct (H2a), moderate values in the attention dimension would indicate a better perception of health, as well as higher scores in clarity (H2b) and repair $(\mathrm{H} 2 \mathrm{c})$. High values in all of the EI dimensions (H3) will act as a protective factor against burnout and also, they would moderate the relationship between burnout and health, decreasing its negative effects (H4).

With regard to burnout syndrome, higher values in both scales would have a positive relation with more health problems and this perception of burnout would mediate negatively between EI dimensions and the perception of health (H5).

\section{Material and method}

\section{Participants}

The present study is based on a sample of 4099 federated football referees from Spain, composed of both men and women, between the ages of 14 and 66 years old, of which 3773 (92.05\%) were men and 326 (7.95 $\%)$ women. Regarding the age's group they were determined in 9 groups as follows: (1) 14-19; (2) 20-25; (3) $36-31$; (4) $32-37$; (5)38-43; (6) 44-49; (7) 50-55; (8) 56-61; (9) 61-66.

Information on the most relevant sociodemographic characteristics of the sample (Table 1) of the present study is attached. The criteria for including the referees in the study were: a) being officially registered in the corresponding federation; b) having Spanish citizenship; c) being at least 14 years old; d) agreeing to participate in the research; e) signing the free and informed consent form; f) exclusion of unfinished or errored protocols; $g$ ) participation of minors required parental consent.

\section{Instruments}

Self-reporting measures enable the appraisal of EI skills, and this method is the one most frequently used to evaluate EI. Such an evaluation takes into consideration interpersonal aspects like the ability to attend to, understand, and repair one's own emotional states (April, Lifson \& Noakes, 2012). The Trait Meta-Mood Scale (TMMS-24) is a reduced and modified version (Fernández-Berrocal et al., 2004) that assesses people's perception of their own emotional abilities and thus improves cognitive processing.

The TMMS-24 measures perceived emotional intelligence (PEI) in its Spanish version (FernandezBerrocal et al., 2004), showing predictive validity of EI in the Spanish population and in different health settings. It consists of 24 items with 3 subscales of 8 items each: attention $(\mathrm{A})$, clarity $(\mathrm{C})$ and repair $(\mathrm{R})$ with Likerttype responses of 5 points $(1=$ Completely disagree to $5=$ Totally agree). The reliability for each subscale was: .80 attention, .81 clarity and .81 repair, with the total being .89 .

Emotional and general health has been assessed using the Spanish version of the 12-item General Health Questionnaire (GHQ-12; Sánchez \& Dresch, 2008; Goldberg, 1978). A 12 -item version is used because of its brevity and fast administration, scored using a Likerttype scale with four points. Although it can be used two-dimensionally, in this study, it is applied onedimensionally (Padrón et al., 2012), where a higher score in the dimension in question represents a worse perception of health and psychological distress (values between 0 and 36). Scores below 12 points represent a good perception of health, between 12-25 points 
indicates a worse perception of health, and between 25 36 points reflect a very bad perception of health. The GHQ-12 shows good psychometric properties, with a Cronbach's Alpha of .76, and demonstrated appropriate levels of reliability and validity in the Spanish population. The GHQ-12 can be used effectively to assess psychological well-being, and to detect non-psychotic psychiatric problems. It also performs better when employed as a multidimensional scale that assesses various aspects of psychological distress, than used as a single screening measure.

The Oldenburg Burnout Inventory (OLBI; Demerouti et al., 2003), is used to assess exhaustion in any type of occupation. It evaluates the two most important components of burnout, emotional exhaustion and disconnection from work, using two dimensions of seven items answered on four-point Likert-type scales. This questionnaire was adapted in a previous study of medical students through a process of translation and back translation (Salamero et al., 2012). A Cronbach's á coefficient of .80 was obtained for the exhaustion scale and one of .67 for the lack of commitment scale. It should be noted that in order to achieve an adequate factorial validity (Campos, Carlotto \& Maroco, 2012) an item was excluded from each dimension of the instrument because the confirmatory factor analysis indicated that the factorial weights of the items (5 on the Disconnection dimension and 13 on the Exhaustion dimension of the original version) were below the desired values. A similar approach had been adopted in a longitudinal study on resident interns (MIR; Salamero et al., 2015).

\section{Procedure}

This investigation is a cross-sectional study. To collect the data, computerized versions of theTMMS-24, OLBI and GHQ-12 were given, in that order, to the participants to be answered on-line. Included in this telematic questionnaire was a first part consisting of sociodemographic data collection, such as age, category, years of experience and gender.

The delegates and heads of each federal delegation of territorial referees, as well as the National Committee of Referees, were previously informed about the objectives of the study and its procedure. The participating referees responded confidentially and voluntarily to three protocols online. In its application, the anonymity of the participants was ensured, and it was explained beforehand that the results would be used solely and exclusively for research purposes. To enable the participation of minors, parental authorization was required, which was expressed through them giving their informed consent in writing. In these cases, each parent was informed by email about the objective of the study and how the information was to be used, as well as guaranteeing the protection of the data of each of the participants. This research has followed the guidelines established in the Declaration of Helsinki (World Medical Association, 2008), regarding research projects, in addition to Spanish national legislation on clinical trials (Law 223/2004 of February 6), biomedical research (Law 14/2007 of July 3) and confidentiality of participants (Law 15/1999 of December 13).

\section{Statistical analysis}

For the descriptive statistical analysis, the SPSS 26.0 program was used. First, the database was explored in order to verify compliance with the statistical assumptions. Subsequently, a descriptive analysis was carried out to show the scores of the different study subgroups for each of the objective groups of the research. Next, the exploratory model was performed using SmartPLS 3.2.9 software (Ringle et al., 2017), with one of the objectives being the ability to estimate the relationship between multiple independent and dependent constructs and the capacity to predict the study variables. The application uses a variance-based structural equation modelling (SEM) approach that enables many independent variables to be handled at the same time. Goodness of fit values have been considered using the standardized mean square root standardized root mean squared residual (SRMR).

\section{Results}

First, differences for health problems, EI dimensions and burnout are explored for the demographic variables of interest (Table 1) namely years of experience and category.

Then the demographic variables were differentiated between different age group (Table 2) of the study.

The next step was to explore correlations between our variables of interest. To do so, we applied a Pearson correlation. The significant positive and negative correlations are shown in Table 3.

As the correlations between our variables of interest proved to be significant, we proceeded to establish our model. 
Table. 1

\begin{tabular}{lcccc}
\multicolumn{5}{l}{ Descriptive statistics between different dimensions of the scales and sociodemographic variables } \\
\hline Experience & $\chi^{2}$ & $\mathrm{df}$ & $\mathrm{p}$ & $\varepsilon^{2}$ \\
\hline Attention & 24.4 & 8 & .002 & .00596 \\
Clarity & 25.6 & 8 & .001 & .00625 \\
Repair & 27.6 & 8 & $<.001$ & .00674 \\
Health Problems & 61.8 & 8 & $<.001$ & .01509 \\
Disengagement (OLBI) & 26.9 & 8 & $<.001$ & .00657 \\
Exhaustion (OLBI) & 27.3 & 8 & $<.001$ & .00666 \\
Total burnout (OLBI) & 28.4 & 8 & $<.001$ & .00692 \\
\hline Category & $\chi^{2}$ & $\mathrm{df}$ & $\mathrm{p}$ & $\varepsilon^{2}$ \\
\hline Attention & 6.46 & 8 & .596 & .00158 \\
Clarity & 37.40 & 8 & $<.001$ & .00913 \\
Repair & 41.68 & 8 & $<.001$ & .01017 \\
Health Problems & 114.02 & 8 & $<.001$ & .02782 \\
Disengagement (OLBI) & 21.13 & 8 & .007 & .00516 \\
Exhaustion (OLBI) & 43.77 & 8 & $<.001$ & .01068 \\
Total burnout (OLBI) & 35.85 & 8 & $<.001$ & .00875 \\
\hline Age & $\chi^{2}$ & $\mathrm{df}$ & $\mathrm{p}$ & $\varepsilon^{2}$ \\
\hline Attention & 21.8 & 8 & .005 & .00532 \\
Clarity & 45.4 & 8 & $<.001$ & .01107 \\
Repair & 36.1 & 8 & $<.001$ & .00882 \\
Health Problems & 53.0 & 8 & $<.001$ & .01294 \\
Disengagement (OLBI) & 15.7 & 8 & .047 & .00383 \\
Exhaustion (OLBI) & 31.9 & 8 & $<.001$ & .00778 \\
Total burnout (OLBI) & 14.7 & 8 & $<.065$ & .00359 \\
\hline Note. Descriptive for experience, category and age &
\end{tabular}

Table. 2

Differences between group depending on experience, category and ag

\begin{tabular}{|c|c|c|c|c|}
\hline \multicolumn{3}{|c|}{ Experience Relationship between groups } & \multirow{2}{*}{$\begin{array}{c}\text { W } \\
5.913\end{array}$} & \multirow{2}{*}{$\frac{\mathbf{p}}{<.001}$} \\
\hline Clarity & 8 & 9 & & \\
\hline & 2 & 9 & 6.283 & $<.001$ \\
\hline \multirow[t]{2}{*}{ Repair } & 8 & 9 & 6.459 & $<.001$ \\
\hline & 1 & 9 & 6.178 & $<.001$ \\
\hline \multirow[t]{8}{*}{ Health Problems } & 6 & 9 & -6.8634 & $<.001$ \\
\hline & 8 & 9 & -10.5426 & $<.001$ \\
\hline & 3 & 9 & -8.9259 & $<.001$ \\
\hline & 5 & 9 & -8.2041 & $<.001$ \\
\hline & 2 & 9 & -9.8915 & $<.001$ \\
\hline & 4 & 9 & -8.3428 & $<.001$ \\
\hline & 1 & 9 & -9.7931 & $<.001$ \\
\hline & 7 & 9 & -7.7114 & $<.001$ \\
\hline Disengagement (OLBI) & 4 & 9 & -6.044 & $<.001$ \\
\hline \multirow[t]{3}{*}{ Exhaustion (OLBI) } & 3 & 9 & -5.919 & $<.001$ \\
\hline & 2 & 9 & -6.332 & $<.001$ \\
\hline & 1 & 9 & -6.337 & $<.001$ \\
\hline \multirow[t]{5}{*}{ Total Burnout (OLBI) } & 8 & 9 & -5.9216 & $<.001$ \\
\hline & 3 & 9 & -6.5043 & $<.001$ \\
\hline & 2 & 9 & -6.5631 & $<.001$ \\
\hline & 4 & 9 & -6.1109 & $<.001$ \\
\hline & 1 & 9 & -6.1717 & $<.001$ \\
\hline \multicolumn{3}{|c|}{ Category Relationship between groups } & W & $\mathrm{p}$ \\
\hline \multirow[t]{2}{*}{ Clarify } & 9 & 3 & -6.151 & $<.001$ \\
\hline & 3 & 7 & 5.996 & $<.001$ \\
\hline \multirow[t]{12}{*}{ Health Problems } & 4 & 9 & -8.2783 & $<.001$ \\
\hline & 4 & 7 & -5.9187 & $<.001$ \\
\hline & 1 & 9 & -9.0676 & $<.001$ \\
\hline & 1 & 8 & -6.6659 & $<.001$ \\
\hline & 1 & 7 & -8.3366 & $<.001$ \\
\hline & 2 & 9 & -9.0732 & $<.001$ \\
\hline & 2 & 8 & -6.6794 & $<.001$ \\
\hline & 2 & 7 & -8.2442 & $<.001$ \\
\hline & 9 & 3 & 8.7297 & $<.001$ \\
\hline & 9 & 6 & 6.8548 & $<.001$ \\
\hline & 8 & 3 & 7.2194 & $<.001$ \\
\hline & 3 & 7 & -7.1956 & $<.001$ \\
\hline Exhaustion (OLBI) & 4 & 1 & 5.927 & $<.001$ \\
\hline \multicolumn{3}{|c|}{ Age Relationship between groups } & W & $\mathrm{p}$ \\
\hline \multirow[t]{2}{*}{ Attention } & 2 & 4 & -5.3212 & .005 \\
\hline & 1 & 4 & -4.4173 & .047 \\
\hline \multirow[t]{5}{*}{ Clarity } & 7 & 5 & 4.831 & .018 \\
\hline & 2 & 5 & 5.718 & .002 \\
\hline & 1 & 3 & 6.379 & $<.001$ \\
\hline & 1 & 4 & 4.646 & .028 \\
\hline & 1 & 5 & 7.293 & $<.001$ \\
\hline \multirow[t]{3}{*}{ Repair } & 2 & 1 & -4.5383 & .036 \\
\hline & 1 & 3 & 6.5030 & $<.001$ \\
\hline & 1 & 5 & 6.2586 & $<.001$ \\
\hline \multirow[t]{7}{*}{ Health Problems } & 2 & 4 & -5.850 & .001 \\
\hline & 2 & 5 & -5.934 & $<.001$ \\
\hline & 1 & 6 & -4.543 & .036 \\
\hline & 1 & 3 & -4.998 & .012 \\
\hline & 1 & 4 & -7.148 & $<.001$ \\
\hline & 1 & 5 & -7.110 & $<.001$ \\
\hline & 2 & 5 & -5.8302 & .001 \\
\hline Exhaustion (OLBI) & 1 & 5 & -5.4285 & .004 \\
\hline
\end{tabular}

Note. signiche
Table. 3

Pearson correlations between the dimension scal

\begin{tabular}{|c|c|c|c|c|c|c|c|c|}
\hline & & 1 & 2 & 3 & 4 & 5 & 6 & 7 \\
\hline 1.Attention & $\begin{array}{l}\text { Pearson's r } \\
\text { p-value }\end{array}$ & - & & & & & & \\
\hline 2.Clarity & $\begin{array}{l}\text { Pearson's r } \\
\text { p-value }\end{array}$ & $\begin{array}{c}.178 * * * \\
<.001\end{array}$ & - & & & & & \\
\hline 3.Repair & $\begin{array}{l}\text { Pearson's r } \\
\text { p-value }\end{array}$ & $\begin{array}{l}.123 * * * \\
<.001\end{array}$ & $\begin{array}{l}.461 * * * \\
<.001\end{array}$ & - & & & & \\
\hline 4.GHQ & $\begin{array}{l}\text { Pearson's r } \\
\text { p-value }\end{array}$ & $\begin{array}{l}.217 * * * \\
<.001\end{array}$ & $\begin{array}{c}-.434 * * * \\
<.001\end{array}$ & $\begin{array}{c}-.436 * * * \\
<.001\end{array}$ & - & & & \\
\hline 5. Disengagement & $\begin{array}{l}\text { Pearson's r } \\
\text { p-value }\end{array}$ & $\begin{array}{l}.029 \\
.061\end{array}$ & $\begin{array}{c}-.103 * * * \\
<.001\end{array}$ & $\begin{array}{l}-.168 \\
<.001\end{array}$ & $\begin{array}{l}.257 * * * \\
<.001\end{array}$ & & & \\
\hline 6. Exhaustion & $\begin{array}{l}\text { Pearson's } r \\
\text { p-value }\end{array}$ & $\begin{array}{l}.078 * * * \\
<.001\end{array}$ & $\begin{array}{c}-.175 * * * \\
<.001\end{array}$ & $\begin{array}{c}-.197 * * * \\
<.001\end{array}$ & $\begin{array}{c}-347 * * * * \\
<.001\end{array}$ & $\begin{array}{l}.721 * * * \\
<.001\end{array}$ & - & \\
\hline 7.OLBI & $\begin{array}{l}\text { Pearson's r } \\
\text { p-value }\end{array}$ & $\begin{array}{c}.056 * * * \\
<.001\end{array}$ & $\begin{array}{c}-.147 * * * \\
<.001\end{array}$ & $\begin{array}{c}-.196 * * * * \\
<.001\end{array}$ & $\begin{array}{l}.323 * * * * \\
<.001\end{array}$ & $\begin{array}{l}.936 * * * \\
<.001\end{array}$ & $\begin{array}{l}.918^{* * * *} \\
<.001\end{array}$ & \\
\hline
\end{tabular}

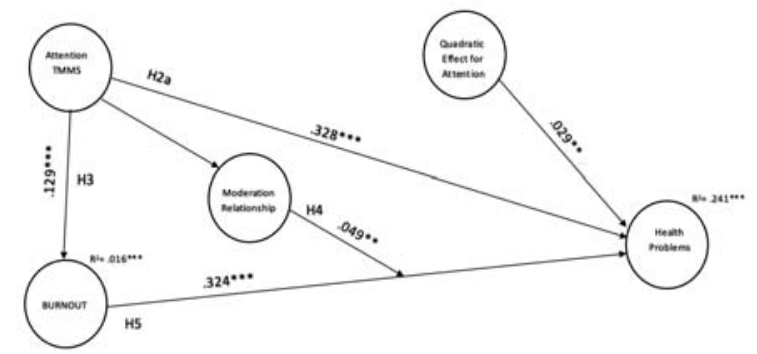

Figure 1. Standardized coefficients for the model including attention's dimension, burnout, lack of health with quadratic and moderating effects. Note $n=4099, * * * p<0.001$

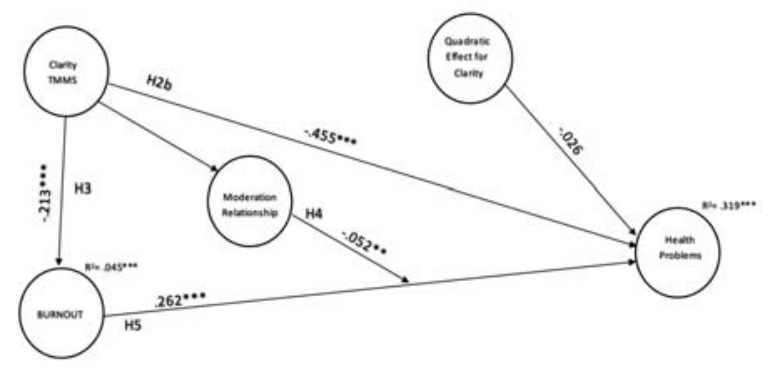

Figure 2. Standardized coefficients for the model including clarity's dimension, burnout, lack of health with quadratic and moderating effects. Note $n=4099, * * * p<0.001$

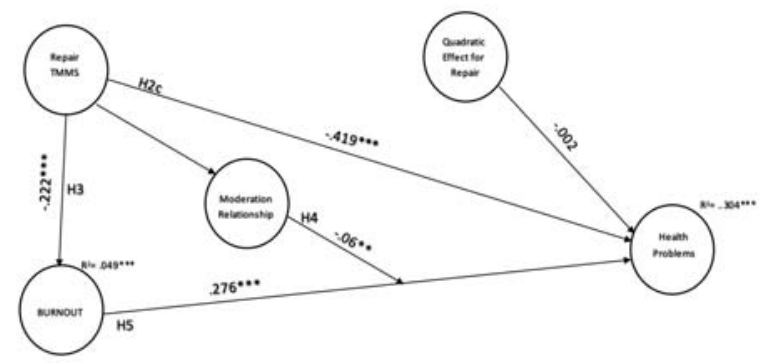

Figure 3. Standardized coefficients for the model including repair's dimension, burnout, lack of health with quadratic and moderating effects. Note $n=4099, * * * p<0.001$

\section{Analysis results}

To establish the measurement model, factor loadings and weights were evaluated for both reflective and formative constructs. Only item 23 of the repair dimension rated a factor loading lower than .4, so it was decided to eliminate it from the analysis (Ringle, 2017).

The following step was to assess the reliability and validity of reflective constructs. Different criteria are used to measure the reliability or internal consistency of a psychometric instrument: Cronbach's alpha, 
composite reliability and the rho reliability coefficient. The values in the study were above .80 for all of the specified indices. Next the convergent validity could be explored, using Average Variance Extracted (AVE), which shows the degree to which a latent construct explains the variance of his indicators. All values (Table 4) were shown to be higher than .5, so it can be assumed that the model has an optimal level of convergent validity.

Subsequently, to ascertain discriminant validity, the heterotrait-monotrait (HTMT; Ringle et al., 2017) was employed. The HTMT is an estimate of factorial correlation. To distinguish between two factors, the HTMT must be significantly less than 1. Ringle et al. (2017) suggested that the values should be below .9 or, preferably, below .85 . In Table 5 , it can be seen that results showed all our constructs to have the requisite discriminant validity.

Once the measurement model is assessed, the structural model can be employed to explore linear regression effects of the endogenous construct upon one another (Ringle et al., 2017) by specifying the pattern of the relationship among the various constructs. To do

Table. 4

\begin{tabular}{lcccc}
\multicolumn{2}{l}{ Construct reliability and validity } \\
\hline $\begin{array}{c}\text { Cronbach's } \\
\text { Alpha }\end{array}$ & rho_A & $\begin{array}{c}\text { Composite } \\
\text { Reliability }\end{array}$ & $\begin{array}{c}\text { Average Variance } \\
\text { Extracted (AVE) }\end{array}$ \\
\hline $\begin{array}{l}\text { Attention } \\
\text { Clarity }\end{array}$ & .879 & .919 & .897 & .525 \\
Repair & .875 & .885 & .901 & .534 \\
\hline Note. Reflective variables analysis with rho_A:1 for constructs (burnout, lack of health),
\end{tabular}

Note. Reflective variables analysis with rho_A:1 for constructs (burnout, lack of health), moderating and quadratic effects

Table. 5

Discriminant validity

\begin{tabular}{llll}
\hline Attention dimension model & Attention & Moderating Effect EI & Quadratic Effect EI
\end{tabular}

Moderating Effect EI $\quad 026$ Attention Moderating Effect El Quadratic Effect El

Moderating Effect EI

\begin{tabular}{lccc} 
Quadratic Effect EI & .084 & .175 & \\
\hline Clarity dimension model & Clarity & Moderating Effect EI & Quadratic Effect EI \\
\hline
\end{tabular}

Moderating Effect $1 \quad .053$

\begin{tabular}{lrrr} 
Quadratic Effect 1 & .239 & .273 & \\
\hline Repair dimension model & Repair & Moderating Effect EI & Quadratic Effect EI \\
\hline
\end{tabular}

Moderating Effect 1

$\begin{array}{lll}\text { Quadratic Effect } 1 & .034 & .288\end{array}$

Note. Heterotrait-monotrait (HTMT) for each model

Table 6

Path analysis: Direct and moderation relationships

Attention dimension model

Attention->Burnout

Attention->Burnout

Attention- $>$ Health Problems
Burnout $->$ Health Problems

Burnout- $>$ Health Problems

Moderating Effect Attention->Health Problems

\begin{tabular}{llllllll} 
Quadratic Effect Attention->Health Problems & .029 & .05 & .017 & 2.933 & .003 \\
\hline
\end{tabular}

Clarity dimension model

\begin{tabular}{lccccc}
\hline Burnout $->$ Health Problems & $\mathrm{O}$ & $\mathrm{M}$ & STEDV & O/STDEV P-Values \\
\hline & .262 & .264 & .019 & 13.889 & .000
\end{tabular}

$\begin{array}{llllll}\text { Clarity }>>\text { Burnout } & -.213 & -.217 & .016 & 13.144 & 000\end{array}$

Chrity $>$ Health Problems

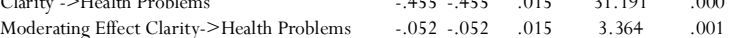

\begin{tabular}{llllll} 
Quadratic Effect Clarity->Health Problems & -.026 & -.026 & .011 & 2.307 & .021 \\
\hline
\end{tabular}

\begin{tabular}{lccccc}
\hline Repair dimension model & $\mathrm{O}$ & $\mathrm{M}$ & STEDV & O/STDEV & P-Values \\
\hline Burnout- $>$ Health Problems & .276 & .279 & .018 & 15.287 & .000
\end{tabular}

\begin{tabular}{llllll}
\hline Burnout- $>$ Health Problems & .276 & .279 & .018 & 15.287 & .000 \\
Repair $->$ Burnout & -.222 & -.226 & .016 & 13.586 & .000 \\
& -.219 & -.418 & .015 & 27.921 & .000
\end{tabular}

Repair -> Health Problems $\quad \begin{array}{llllll}-.419 & -.418 & .015 & 27.921 & .000\end{array}$

$\begin{array}{llllll}\text { Moderating Effect Repair->Health Problems } & -.06 & -.06 & .017 & 3.641 & .000\end{array}$

$\begin{array}{llllll}\text { Quadratic Effect Repair->Health Problems } & -.002 & -.002 & .012 & .181 & .0066\end{array}$

Note. Original Sample (O); Sample Mean (M); Standard Deviation (SDETV); T Statistics (O/STDEV)

Table 7.

Mediation relationships

\begin{tabular}{lccccc}
\hline & $\mathrm{O}$ & $\mathrm{M}$ & STEDV & $\mathrm{O} / \mathrm{STDEV}$ & P-Values \\
\hline Clarity->Burnout->Health Problems & -.056 & -.057 & .006 & 9.242 & .000 \\
Attention->Burnout- $>$ Health Problems & .042 & .044 & .006 & 6.629 & .000 \\
Repair-> Burnout $->$ Health Problems &. .061 & -.063 & .006 & 9.803 & .000 \\
\hline Note. Original Sample (O); Sample Mean (M); Standard Deviation (SDETV); T Statistics
\end{tabular}

Note. Original Sample (O); Sample Mean (M); Standard Deviation (SDETV); T Statistics (O/STDEV so, multicollinearity effects are first evaluated with Variance Inflation Factor (VIF). None of the values were superior than 10 , so absence of collinearity can be assumed. Another important aspect that must be taken into account is goodness of fit. The models related with each dimension of EI showed an acceptable goodness of fit with these relationships, with standardized root mean squared residual (SRMR) of .052, .036 and .031 for attention, clarity, and repair respectively.

Next, the relationship of our variables was assessed, evaluating path coefficients ( $\hat{a})$ and their significance (pvalue). Table 6 show direct and moderating effects for each EI dimension's model, and Table 7 present mediation effects.

\section{Direct effects}

Table 6 shows a positive effect on burnout $(\beta=.129$, $\mathrm{p}<.001)$ and health problems $(\beta=.328, \mathrm{p}<.001)$ for the attention dimension model. Taking into account the clarity dimension model, it had a negative effect on burnout $(\beta=-.213, \mathrm{p}<.001)$ and health problems $(\beta=$ $.455, \mathrm{p}<.001)$. Finally, as for the repair dimension model, it had a negative effect on burnout $(\beta=-.222, p<.001)$ and health problems $(\beta=-.419, \mathrm{p}<.001)$.

As shown in Table 7, the three dimensions of EI act as moderators of health in the presence of burnout syndrome, maintaining a positive relationship with the attention dimension $(\beta=.042, \mathrm{p}<.001)$, and a negative relationship with clarity $(\beta=-.056, \mathrm{p}<.001)$ and repair $(\beta=-.061, p<.001)$.

In our study, from the perspective of the attention dimension model, the $\mathrm{R}^{2}$ of the burnout scale (.016) and health problems (.241) would indicate a strong coefficient. Furthermore, the $\mathrm{R}^{2}$ of the clarity dimension model for burnout (.045) and health problems (.319), and the $\mathrm{R}^{2}$ of the repair dimension model for burnout (.049) and health problems (.304) also gave strong coefficients of determination.

\section{Indirect mediation effects}

From the attention dimension model, burnout shows a positive effect with regard to health problems $(\beta=.324, p<.001)$ and a positive moderating effect of attention to health problems $(\beta=.049, \mathrm{p}<.01)$ is also shown. On the other hand, from the clarity dimension model, burnout shows a positive effect in terms of health problems $(\beta=.262, \mathrm{p}<.001)$ but a negative moderating clarity effect when it comes to health problems $(\beta=$ $.052, \mathrm{p}<.01)$. The same happens with the repair dimension model, where the burnout construct shows 
a positive effect $(\beta=.276, \mathrm{p}<.001)$ in relation to health problems and a negative moderating repair effect with regard to health problems $(\beta=-.06, \mathrm{p}<.001)$.

Thus, scales such as attention, clarity and emotional repair of EI are those that display high strength relationships, specifically in relation to the subjective perception of health problems and in terms of the dimensions of burnout. In other words, as far as participation is concerned, the referees displayed high levels in three EI dimensions, especially in repair and clarity with reference to the health problems and burnout dimensions. Regarding the burnout dimensions, it indicated high levels in health problems.

The next stage was be to evaluate the coefficient of determination of our endogenous construct. The Coefficient of Determination $\left(\mathrm{R}^{2}\right)$ denotes the quantity of variation in the dependent variables that can be explained by one or more predictors, which range between 0 and +1 , and indicate the predictive precision of the structural variable model. The cut-off values of $.19, .33$ and .67 indicate a weak, moderate and strong coefficient of determination respectively, this being a reflective model (Chin, 1998). Table 8 presents the results found. Considering all EI dimension in one model and the levels of burnout together, $44.8 \%(\mathrm{p}<.000)$ of health problems' variability can be explained.

In terms of the effect size, according to Cohen (1998): $f^{2} \geq .02, f^{2} \geq .15$, and $f^{2} \geq .35$ represent small, medium and large sizes respectively (Selya et al., 2012). Table 9 displays the results for our variables. In the study, the

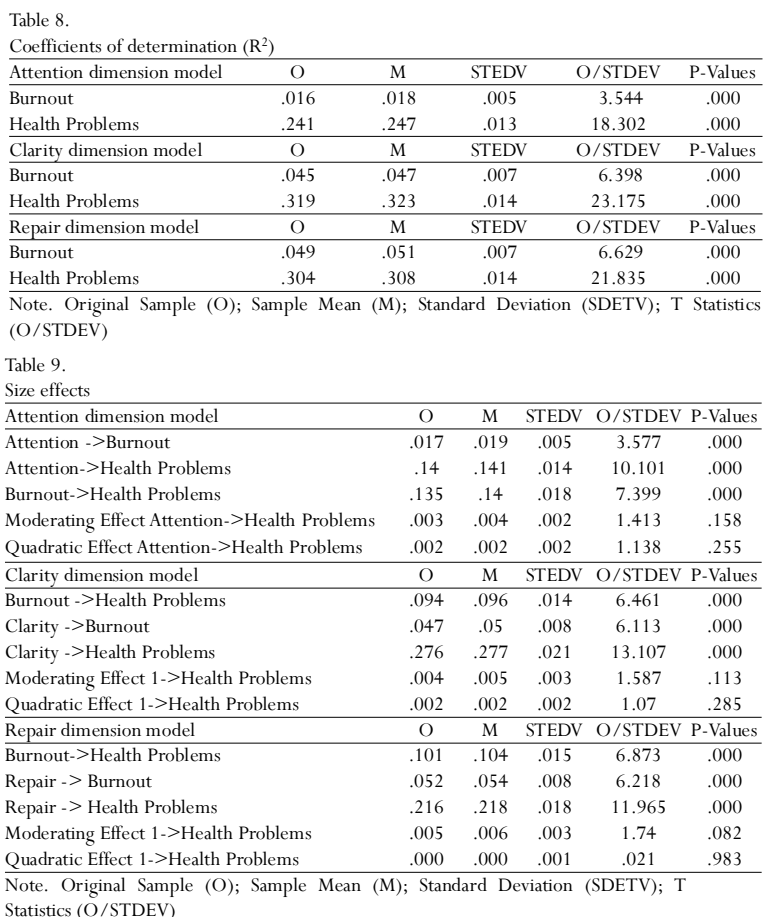

effect size for the attention dimension model would be medium for burnout $(.017 ; \mathrm{p}<.000)$ and small for health problems in terms of attention $(.014 ; \mathrm{p}<.000)$ as well as burnout $(.135 ; \mathrm{p}<.000)$.

The effect size for the clarity dimension model would be small when it comes to burnout $(.047 ; \mathrm{p}<.000)$, medium regarding health problems $(.276 ; \mathrm{p}<.000)$, and small for burnout in relation to health problems (.094; $\mathrm{p}<.000)$. Finally, the effect size for repair dimension model would be small for burnout $(.052 ; \mathrm{p}<.000)$, and medium with regard to health problems $(.216 ; \mathrm{p}<.000)$. Regarding burnout in relation to health problems, the size would be small $(.101 ; \mathrm{p}<.000)$.

Finally, to assess predictive power of the model, the blindfolding technique was applied. $\mathrm{Q}^{2}$ values greater than $0, .15$, and .35 represent small, medium, and large predictive relevance of the PLS path model. Similar to the effect sizes $f^{2}$, it is possible to calculate and interpret the effect sizes $\mathrm{Q}^{2}$. As observed in the $\mathrm{Q}^{2}$ of the analysis, the predictive power of the model is small (Ringle et al., 2019) and all the values were under .15.

\section{Discussion}

Being a referee involves managing and dealing with various technical, tactical, and physical issues, but also psychological ones (Soriano et al., 2018). The present research aimed to analyse the relationships and interactions between the different dimensions of EI (attention, clarity, repair), burnout (disconnection and exhaustion) and subjective perception of health in amateur and professional Spanish football referees.

Results such as those of the present study show the need to analyse the impact of EI and burnout on referees, as well as to explore their relationship with the subjective perception of health and the associated consequences in the field where they work. Among the variables that predict health, the dimension of attention, clarity, and repair features directly and specifically, with burnout having a mediating role between EI and perceived health, according to the results obtained.

Regarding burnout, some authors (Mendes, Travassos \& Patricia, 2020; Aguirre et al., 2016) comment that it constitutes a dimension related to mental health and pressure at work. In our study, the perception of health is explained directly by the burnout dimension (H5), which would be influenced in terms of moderating their effect by all the TMMS scales (H4). In higher values in both scales of burnout will have a positive relation with a higher frequency of health problems (H5). Some studies 
corroborate (Figueroa \& Patiño, 2021) that burnout syndrome has an incidence in the injuries of athletes, while other authors (Prendas, Castro \& Vargas, 2007) show that Costa Rican and Brazilian football referees (Santos et al., 2021) with a high risk of suffering burnout have a strong correlation with depressive symptoms, hostility, and fatigue.

In our study, the EI dimensions act as a moderator between burnout and the frequency of experiencing health problems (H4). This relationship is positive for attention and negative for clarity and repair, which indicates that the higher the scores with regard to attention, then the higher positive effect of burnout over health problems will be. In other words, referees who have higher scores of attention will show a stronger relationship between burnout and health problems. Just the opposite is found to be the case with clarity and repair dimensions in relation to EI dimensions. In this study, clarity and repair shows a negative moderating influence between burnout and health problems.

In light of all this, it appears that clarity and repair dimensions of EI are directly related to better selfperceived health status of referees (H2b \& H2c), and that also attention EI (H2a) shows a positive influence in terms of experiencing an increasing number of health problems and greater burnout, as well as being a positive moderator of the aforementioned burnout construct and health problems (H4). Examples that support our results can be found in a study (Castro, et al., 2020) that relates EI and anxiety (Fernández-Berrocal et al., 2016), and in other (González, Ros, Jiménez \& Garcés, 2014) where the relationship between EI and burnout in athletes is reflected; and one (Sánchez \& Breso, 2020) which shows that high EI predicts better sports performance and presents burnout as a mediating agent.

In other professional fields, similar indications to those found in the present research also appear, such as a study (Berrios, Pulido, Augusto \& López, 2020) on nursing and teaching groups, which confirms the hypothesis that EI acts as a resource that lessens the negative effects of stress (H2b; H2c) and burnout (H3), and facilitates better psychological well-being (H4). In addition, other studies (Servian, Vera, Brítez \& Rodríguez, 2019) show the association between mental health and burnout in health professionals who are exposed to great stress (H5). The EI construct has also been explored as a mediator between burnout and job performance (Sánchez \& Breso, 2020).

Thus, the role of EI and its relationship between burnout and subjective perception of health is reflected in this research. Referees with higher EI also seem to be less affected by the negative consequences associated with burnout (H3). Findings are in keeping with these results, and also consolidate the role of EI as a protective factor against negative effects (Membrive et al., 2020). A study (Laborde et al., 2015) have also shown a positive relationship between high EI scores and enhanced sports performance, and other study (Nurcahya, Mulyana \& Sagitarius, 2019) as well as lower levels of stress and the presence of a greater number of pleasant emotions. Research indicates that athletes with low levels of anxiety are ones with higher levels of EI (Castro, et al., 2020). In this sense, and according to the literature, the hypothesis (H3) is recognized, showing the importance of high scores and a negative relationship between clarity and repair with regard to health problems (H2b; H2c) and burnout (H3). In addition, those previously mentioned dimensions then act to counter the negative effect caused by high positive scores in attention (H3) to burnout and in health problems (H2a).

Concerning the dimensions of EI, some publications have found moderate scores in attention (FernándezBerrocal et al., 2012) and high scores in clarity and repair to be markers of better psychological adaptation to burnout. In our study, football referees show a positive relationship between attention $(\mathrm{H} 2 \mathrm{a})$ and health problems. That said, a significant negative relationship for clarity $(\mathrm{H} 2 \mathrm{~b})$ and repair $(\mathrm{H} 2 \mathrm{c})$ permits us to indicate a better perception of health. Several studies also relate high scores in clarity and repair dimensions with the perception of having healthier life and lower risk behaviours (Sánchez et al., 2018). In the present study, in addition to confirming hypotheses $(\mathrm{H} 2 \mathrm{a} ; \mathrm{H} 2 \mathrm{~b} ; \mathrm{H} 2 \mathrm{c}$ and $\mathrm{H} 4$ ), the relationship that connects clarity and reparation with health is negative one, supporting to the findings in part of the literature.

EI is a protective and moderating factor, which makes us less vulnerable to burnout and health problems. The results of the study tie in with several investigations (Fernandez-Berrocal et al., 2006) where clarity and repair negatively correlate with anxiety and depression, while attention does so in a positive sense.

Furthermore, the results obtained in these two scales are significantly strong scores, which suggest that (as shown in the analysis model) higher scores in these dimensions would act as a protective factor to avoid burnout (H3), and as a result, they would help in the perception of better health status, confirming the hypothesis ( $\mathrm{H} 2 \mathrm{a}, \mathrm{H} 2 \mathrm{~b} \& \mathrm{H} 2 \mathrm{c}$ ), and decreasing the negative effects. 
It is worth highlighting the mediating relationship established by burnout between all dimensions of EI and health problems (H4). From the results, it can be extracted that the EI dimensions act as a powerful burnout reducer, thereby facilitating an improvement in the referees' perception of health, and thus confirming the established hypothesis (H4).

It is also extracted that very high scores in attention would be related to a worse subjective perception of health and burnout (H2a; H3). It should be noted that the other two dimensions of EI, clarity and repair, may act as a protective factor both on burnout (H3) and on health problems (H4).

Regarding the objective of our study, and taking into account the demographic variables of the research, some authors (Da Gama et al., 2018) show that there is a negative correlation between the Years as Referee (experience) variable and burnout scores in professionals, which shows that the more years they had refereed, the lower degrees of stress they exhibited. In addition to this, studies (Karademir, 2012; Al-Haliq, Altahayneh \& Oudat, 2014) on Turkish and Jordanian referees, respectively, showed reductions in levels of exhaustion and stress after more years of experience. In our study, by way of contrast, burnout values revealed different patterns as refereeing experience is gained, in the sense that no linear progression is evident, and the decrease is very small (appearing in age groups 5 to 8 , with the lowest values corresponding to 38-43 years old (group 5), and these values then continuing up to 61 years (group 8). Inactive or retired referees (group 9 corresponding to those of more than 61 years) revealed a sharper decline in burnout values, probably due to the fact that they were no longer directly involved with the sport on the field of play.

Conversely, the study does show a marked decrease in burnout values in referees in higher categories (from group 7 to 9 , in other words, from 2nd division B to 1 st division, with a downward trend being observed in the 1st division (group 9), which has lower burnout). With regard to the variable age, the eldest show a more pronounced decrease in burnout values (in group 5, from 38 to 43 years, the decrease is much more notable when compared to the previous groups). In the following groups, ( 6 to 7 , that is from 44 to 55 years old) there is a slight increase, which then falls once more from 56 years onwards (groups 8-9). This subtle rise from the age of 44 to 55 may be caused by the uncertainty surrounding the end of the refereeing career at the age of 45 , coupled with seeking reintegration into the world of work. Alternatively, results with referees from the Turkish league (Sirin \& Dosylmaz, 2017) show that burnout levels in referees who have worked for between 7-9 seasons are higher than in those with fewer years of experience. Other authors (Oliveira, Penna \& Pires, 2017) highlight the need for caution when affirming that referees with more experience can handle adverse circumstances better.

With regard to the category variable, the study reflects that in semi-professional categories (3rd division) and, particularly, in professional ones (1st and 2nd division), referees have a lower perception of health problems. These findings are in line with those of a study (Acebes et al., 2020) with professional soccer referees and their relationship with stress and mental health (Arias, et al., 2021).

Furthermore, the present study shows that referees in the previously mentioned categories suffer less burnout, especially at a professional level. Conversely, some authors (Pedrosa \& García, 2015) found that the most experienced and elite referees have a higher tendency to burnout. Having said that, in the category variable of the study, the clarity, and repair dimension values increase progressively and markedly from semiprofessional categories onwards, albeit with the attentional dimension remaining moderate, which thus allows an increased capacity for emotional management. Interestingly, a study with basketball referees (Niebla, 2021) similarly indicates that referees with higher status have a better capacity for emotional management.

Finally, as far as the age variable is concerned, referees aged from 38 to 43 years (group 5) are revealed to be those with the best perception of health and the least burnout, dovetailing with their final phase as active referees. In addition, older participants recorded better results in the emotional dimensions, with referees aged between 38 and 43 (group 5) giving the best results, findings that tie in with another study with basketball referees (Niebla, 2021) where it is shown that referees over the age of 40 have a greater capacity for emotional management. The results would be supported by several authors (Sainz, 2010; Bekendam, 2013; Martín, 2013) who showed that older subjects are more adept at identifying and assessing emotions than younger ones.

In our study, burnout is determined by the positive influence of high scores in attention and the negative influence of significant scores in clarity on the cited construct. In other words, higher scores in clarity dimension and moderate-low scores in attention will be represented in lower burnout scores. This relationship 
does not appear in a linear way, but rather a curve is observed in the quadratic study, suggesting that with more attention, the perception of problems tends to rise sharply before later becoming stable. That shows that the quadratic effect is significant for attention and clarity.

In addition to this, there is a study (Jafarloo et al., 2020) which shows how EI reduce burnout in Iranian female referees. The referees display strong values on the clarity and repair scales, which implies that, even as standardized values, higher scores for these scales in this group would act as a protective agent and reduce burnout, and, as a consequence, result in better selfperception of health.

In relation to the second variable of the study (category), a publication involving professional and amateur referees could not conclude that the former group suffered from a higher degree of burnout compared to latter (Da Gama et al., 2018). In our study, taking this variable into account, the professional referees show high values of clarity and repair and, consequently, lower levels of burnout in their two scales, with enables us to expound that, despite displaying in one form or another the effects of the dimensions of EI and burnout according to the different categories, years of experience and age, the professionals (1st and 2nd division) show high scores in EI, enabling them to mitigate the negative effects. It should be noted that some of these results contradict those shown by other authors (Pedrosa \& García, 2015) in professional Spanish referees. Other authors affirm (Keefer, Holden \& Parker, 2013), that as lived experiences accumulate, EI is progressively enhanced (Sánchez et al., 2021). At the same time, in a study of athletes participating in contact and non-contact sports (Gallardo et al., 2019), it was observed that the subjects who exercise greater emotional control are then able to identify those emotions properly and so use them efficiently, findings that are in tune with the observations of other authors (Salguero et al., 2011). This could be explained by the importance that EI acquires in refereeing as a profession, along with the need to gain many years of experience doing the same activity to enhance performance. This is a factor that, coupled with the acquired practice, would moderate mitigating negative factors.

Finally, another variable of the analysis, age, has also proven to be significant. A recent investigation (Orviz, Botey \& Arce, 2021) found that amateur referees between 23 and 24 years of age show the highest burnout values. In the present study, highly variable differences are observed between age groups and where the youngest subjects do not show the highest levels of burnout.

In short, educating and training referees in various mental skills, especially emotional ones, constitutes an essential initiative that would enable them to face the adversity to which they are exposed and prevent burnout, thus increasing satisfaction and perception of health. Some authors (Mattingly \& Kraiger, 2019), claim that training in EI has a positive effect and improves results in the workplace.

\section{Strengths and limitations}

This research has many strengths, focussing as it does on evaluating the effects of EI in groups like referees, given that it is such a large and poorly studied sample. In addition, the study and exploration of psychological variables in athletes provides the opportunity to improve the referee's performance, providing resources to complete their physical, technical and tactical preparation. As much as it is true that the burnout construct has been extensively studied in the clinical and health field, it must also be taken into account in other groups and activities that mediate extreme and high-pressure circumstances, as is the case with athletes. This study shows, in an exhaustive manner, the importance of EI and its relationship with well-being. At the same time, it manifests the need to educate athletes, coaches, students, and educators of the importance of emotional education and the promotion of emotional competencies in order to improve performance.

One limiting factor of this research is that it is a cross-sectional study and the measurements were only taken at a certain point of the sample, an approach which might have given rise to biases in the sample itself. Another limiting factor is the low representation of women in the group, and, while it may be true that their numbers are increasing in the profession, women are still underrepresented in this field when compared to their male counterparts.

\section{Conclusion}

It is relevant to indicate the importance of psychological aspects in sport, particularly for sportsmen and women. Emotional intelligence is a construct that should be taken into account in sports programming and planning, regardless of the discipline, in order to 
obtain better sports performance, but above all, to act as a preventive factor for burnout and health. These are elements that, if not considered, will affect the sporting performance of referees. Improving EI, and specifically working on the attention, clarity and emotional repair dimensions, will lead to fewer anxious and depressive symptoms, greater life satisfaction and a reduction of negative thoughts. In addition, EI will directly impact on a better subjective state of health, which will enable us to face the task at hand, and, at the same time, protect us from disconnection or exhaustion in our work.

In the near future, it would be of great interest to carry out training activities based on EI and longitudinally analyse their impact on athletes, bearing in mind the demographic variables of the study. Moreover, this type of training in emotional skills or competencies could be promoted by other figures involved in physical activity such as teachers, coaches and technicians, as well as by institutions such as schools, clubs, and similar sporting entities in order to later analyse their impact, both on athletes themselves and on classrooms.

\section{References}

Acebes, J., Granado, M. \& Marchena, C. (2020). Relación entre inteligencia emocional y ansiedad en un club de fútbol sala de Madrid (Relationship between emotional intelligence and anxiety in a futsal club from Madrid). Retos: Nuevas tendencias en Educación Física, Deporte y Recreación, 39, 643-648. doi: doi.org/ 10.47197/retos.v0i39.81975

Arias, Y. A., Tubay, M. F., Chang, W. L., \& Briones, W. R. (2021). Estrés laboral y salud mental de los árbitros de fútbol profesionales, provincia de Los Ríos. Journal of Science and Research, 6(1), 59 - 76.

Aguirre, H., Tristan, J., López, J., Tomás, I. \& Zamarripa. (2016). Estilos interpersonales del entrenador, frustración de las necesidades psicológicas básicas y el burnout: un análisis longitudinal en futbolistas. Retos: Nuevas tendencias en Educación Física, Deporte y Recreación, 30(2), 132-137. doi: doi.org/10.47197/ retos.v0i30.50097

Al-Haliq, M., Altahayneh, Z. L. \& Oudat, M. E. (2014). Levels of burnout among sports referees in Jordan. Journal of Physical Education and Sport, 14(1), 47. doi: doi.org/10.7752/jpes.2014.01008

Anshel, M., Sutarso, T., Ekmekci, R. \& Saraswati, I. (2014). A model linking sources of stress to approach and avoidance coping styles of Turkish basketball referees. Journal of Sports Sciences, 32(2), 116-128. doi: doi.org/10.1080/02640414.2013.816762

April, K., Lifson, D. \& Noakes, T. (2012). Emotional intelligence of elite sports leaders \& elite business leaders. International Journal of Business and Commerce, 1(5), 82-115.

Arbinaga, F., Fernández, E., Herrera, P. \&Vela, D. (2019). Síndrome de burnout y resiliencia en árbitros de fútbol y baloncesto. Revista de Psicología del Deporte/ Journal of Sport Psychology, 28(2), 23-32.

Bar-On, R. (1997). BarOn emotional quotient inventory. Multi-health systems.

Bekendam, N. (2013). Diferencias en inteligencia, inteligencia emocional y personalidad entre nadadores y sujetos sedentarios. Tesis doctoral: Universidad Europea de Madrid.

Bernardo, A., Macedo, E. \& Alvarez D. (2017). Síndrome de Burnout em Árbitros de Futebol. Revista de Psicología del Deporte, 27(1), 31-36

Bennett, J. \& Maynard, I. (2017). Performance blocks in sport: Recommendations for treatment and implications for sport psychology practitioners. Journal of Sport Psychology in Action, 8(1), 60-68. doi: doi.org/10.1080/21520704.2016.1227414

Berrios, M. P., Pulido, M., Augusto, J. \& López, E. (2020). Inteligencia emocional en distintos colectivos: Aportaciones del Grupo Team+. Know and Share Psychology, 1(4). doi:doi.org/10.25115/ kasp.v1i0.4127

Campos, J., Carlotto, M. \& Maroco, J. (2012). Oldenburg Burnout Inventory - student version: cultural adaptation and validation into Portuguese. Psicologia. Reflexao e Crítica. 25(4), 709-718. doi: doi.org/10.1590/S0102-79722012000400010

Cantón, E. \& Checa, I. (2012). Los estados emocionales y su relación con las atribuciones y las expectativas de autoeficacia en el deporte. Revista de psicología del deporte, 21(1), 0171-176.

Carrasco, A. E. R., Campbell, R. Z., López, A. L., Poblete, I. L. \& García, A. (2013). Autonomy, coping strategies and psychological well-being in young professional tennis players. The Spanish journal of psychology, 16. doi: doi.org/10.1017/sjp.2013.70

Castillo, D., Yanci, J., Cámara, J. \& Weston, M. (2016). The influence of soccer match play on physiological and physical performance measures in soccer referees and assistant referees. Journal Sports Sciences, 34(6), 557-563. doi: 10.1080/02640414.2015.1101646

Castro, M., Zurita, F., Ramírez, I. \& Ubago, J. (2020). Relación entre la inteligencia emocional y los niveles de ansiedad en deportistas. Journal of Sport and 
Health Research. 12(1), 42-53. doi: doi.org/10.47197/ retos.v0i39.81975

Cohen, J. (1988). Statistical Power Analysis for the Behavioral Sciences. Mahwah, NJ: Lawrence Erlbaum.

Contessoto, L., Costa, L., Anversa, A. L. \& Refundini, L. (2020). Análisis del nivel de ansiedad precompetitiva en atletas jóvenes y adultos practicantes de Muaythai (Analysis of the level of precompetitive anxiety in young and adult athletes practitioners of Muaythai). Retos: Nuevas tendencias en Educación Física, Deporte y Recreación, 40, 209-215. doi: doi.org/10.47197/retos.v1i40.79849

Da Gama, D., Nunes, R., Guimaraes, G., Silva, L., De Castro, J. \& Vale, R. (2018). Analysis of the burnout levels of soccer referees working at amateur and professional leagues of Rio de Janeiro, Brazil. Journal of Physical Education and Sport, 18, 1168-1174. doi: doi.org/10.7752/jpes.2018.s2174

Demerouti, E., Bakker, A., Vardakou, I. \& Kantas, A. (2003). The convergent validity of two burnout instruments: A multitrait-multimethod analysis. European Journal of Psychological Assessment. 19, 12-23. doi:10.1027/1015-5759.19.1.12

Englert, C., Zwemmer, K., Bertrams, A. \& Oudejans, R. (2015). Ego depletion and attention regulation under pressure: Is a temporary loss of self-control strength indeed related to impaired attention regulation? Journal of Sport and Exercise Psychology, 37(2), 127-137. doi: doi.org/10.1123/ jsep. 2014-0219

Enns, A., Eldridge, G., Montgomery, C. \& Gonzalez, V. (2018). Perceived stress, coping strategies, and emotional intelligence: A cross-sectional study of university students in helping disciplines. Nurse education today, 68, 226-231. doi: doi.org/10.1016/ j.nedt.2018.06.012

Fernandez-Berrocal, P., Berrios, P., Extremera, N. \& Augusto, J. (2012). Inteligencia emocional: 22 anos de avances empiricos. Behavioral Psychology, 20(1), 5 13.

Fernández-Berrocal, P., Extremera, N. \& Ramos, N. (2004). Validity and reliability of the Spanish modified version of the Trait Meta-Mood Scale. Psychological reports, 94(3), 751-755. doi:doi.org/10.2466/pr0.94.3.751-755

Fernández-Berrocal, C., Fava, G. \& Sonino, N. (2016). Contribuciones de la Medicina Psicosomática a la Medicina Clínica y Preventiva. Anales de Psicología, 32(3), 828-836. doi: dx.doi.org/10.6018/ analesps.32.3.219801
Ferreira, R. \& Brandão, M. (2012). Brazilian professional soccer referee: perception of the meaning of refereeing. Revista da Educação Física/UEM, 23(2), 229-238. doi: doi.org/10.4025/ reveducfis.v23i2.15235

Figueroa, M. \& Patiño, V. (2021). Asociación entre síndrome de Burnout y la frecuencia de lesiones deportivas en futbolistas de divisiones inferiores de clubes profesionales del Perú. Tesis doctoral.

Gallardo, M., Domínguez, M. \& González, C. (2019). Inteligencia emocional y conducta agresiva en el deporte ¿Puede inferir la modalidad deportiva y las horas de entrenamiento? Retos: nuevas tendencias en educación física, deporte y recreación, 35, 176-180. doi: doi.org/10.47197/retos.v0i35.66213

García, N., González, J. \& Garcés de los Fayos, E. (2016). Estado actual del estudio del síndrome de burnout en el deporte. Cuadernos de Psicología del Deporte, 16(2), 21-28.

García, B., González, C. \& Salinero, J. (2011). Características psicológicas de los árbitros de waterpolo en España.

Geng, Y. (2018). Gratitude mediates the effect of emotional intelligence on subjective well-being. A structural equation modeling analysis. Journal of health psychology, 23(10), 1378-1386. doi: doi.org/10.1177/ 1359105316677295

Goldberg, D.P. (1978). Manual of the General Health Questionnaire. NFER Publishing: Windsor, UK.

González, J., Ros, A., Jiménez, M. \& Garcés de los Fayos, E. (2014). Análisis de los niveles de burnout en deportistas en función del nivel de inteligencia emocional percibida: el papel moderador de la personalidad. Cuadernos de Psicología del Deporte, 14(3), 39-48.

Gorczynski, P., Coyle, M. \& Gibson, K. (2017). Depressive symptoms in high-performance athletes and non-athletes: A comparative meta-analysis. British Journal of Sports Medicine, 51(18), 1348-1354. doi: doi.org/10.1136/bjsports-2016-096455

Guillén, F. \& Feltz, D. (2011). A conceptual model of referee efficacy. Frontiers in psychology, 2, 25. doi:10.3389/fpsyg.2011.00025

Gustafsson, H., Hancock, D. \& Coté, J. (2014). Describing citation structures in sport burnout literature: A citation network analysis. Psychology of Sport and Exercise, 15(6), 620-626. doi:10.1016/ j.psychsport.2014.07.001

Hamer, M., Stamatakis, E. \& Steptoe, A. (2009). Doseresponse relationship between physical activity and 
mental health: the Scottish Health Survey. British journal of sports medicine, 43(14), 1111-1114. doi: 10.1136/bjsm.2008.046243

Jafarloo, H.R.S., Keshavarz, J. \& Bashiri, M. (2020). The correlation of emotional intelligence with burnout caused by refereeing in female referees of Iranian football. Journal of Health Promotion Management, 9(4), 0-0.

Karademir,T. (2012). The factors that influence the burnout condition of city football referees. Journal of Physical Education and Sport Management, 3(2), 27-34. doi: doi.org/10.5897/JPESM11.071

Keefer, K. V., Holden, R. R. \& Parker, J. D. A. (2013). Longitudinal assessment of trait emotional intelligence: Measurement invariance and construct continuity from late childhood to adolescence. Psychological Assessment, 25(4), 1255 1272. doi: doi.org/10.1037/a0033903

Keyes, C., Shmotkin, D. \& Ryff, C. (2002). Optimizing well-being: the empirical encounter of two traditions. Journal of personality and social psychology, 82(6), 1007. doi: doi.org/10.1037/00223514.82.6.1007

Laborde, S. \& Dosseville, F. (2015). Emotional Intelligence in sport and exercise: A systematic review. Scandinavian Journal of Medicine and Science in Sports. doi: 10.1111/sms. 12510

Laborde, S., Guillén, F., Dosseville, F. \& Allen, M. (2015). Chronotype, sport participation, and positive personality-trait-like individual differences. Chronobiology international, 32(7), 942951. doi: dx.doi.org/10.1016/j.paid.2016.06.009

Latinjak, A., López, V. \& Font, R. (2014). Las emociones en el deporte: Conceptos empleados en un modelo tridimensional. Revista de psicología del deporte, 23(2), 0267-274.

Martín, M. (2013). Análisis de un modelo estructural de inteligencia emocional y motivación autodeterminada en el deporte. Tesis doctoral: Universidad de Valencia.

Maslach, C. \& Jackson, S. (1981). The measurement of experienced burnout. Journal of organizational behavior, 2(2), 99-113.

Mattingly, V. \& Kraiger, K. (2019). Can emotional intelligence be trained? A meta-analytical investigation. Human Resource Management Review, 29(2), 140-155. doi:10.1016/j.hrmr.2018.03.002

Membrive, M., Pradas, L., Suleiman, N., Vargas, K., Cañadas, G., Gómez, J. \& De la Fuente, E. (2020). Burnout in Nursing Managers: A Systematic Review and Meta-Analysis of Related Factors, Levels and Prevalence. International Journal of Environmental Research and Public Health, 17(11), 3983. doi:10.3390/ ijerph17113983

Mendes, S., Travassos, B. \& Patricia, E. (2020). Career development and perception of factors to the excellence of the football referee in Portugal. Retos: Nuevas Perspectivas de Educación Física, Deporte y Recreación, 2041(37), 694-701 . https: / / doi.org/10.47197/ retos.v37i37.74350

Mota, J., Santos, R., Silva, P., Aires, L., Martins, C. \& Vale, S. (2012). Associations between self-rated health with cardiorespiratory fitness and obesity status among adolescence girls. Journal of Physical Activity and Health, 9(3), 378-381. doi: 10.1123/jpah.9.3.378

Narwal, K. \& Sharma, S. (2018). A study of relationship between emotional intelligence and academic stress of visually disabled students. Journal of educational studies trends and practices, 8 (2), 190 -196. doi: 10.52634/mier/2018/v8/i2/1391

Niebla, A. P. (2021). Gestión Emocional, Gestión de Conflictos y Síndrome del Burnout en Árbitros/as de Baloncesto. http://doi.org/10.52634/mier/ 2018/v8/i2/1391

Nurcahya, Y., Mulyana, D. \& Sagitarius, S. (2019). Relationship between emotional intelligence and physical fitness with football referee performance. In 3rd International Conference on Sport Science, Health, and Physical Education (ICSSHPE 2018),136-138, Atlantis Press.

Olivares, E. M. (2020). Síndrome de Burnout en deportistas: análisis de variables psicológicas y psicopatológicas. Tesis doctoral.

Oliveira, A., Penna, E. \& Pires, D. (2017). Sindrome de burnout em arbitros de futebol. Revista de Psicología del Deporte, 27(1), 31-36.

Ong, N. \& Griva, K. (2017). The effect of mental skills training on competitive anxiety in schoolboy rugby players. International Journal of Sport and Exercise Psychology, 15(5), 475-487. doi:10.1080/ 1612197X.2016.1153129

Orviz, N., Botey, M. \& Arce, S. (2021). Analysis of Burnout and Psychosocial Factors in Grassroot Football Referees. International Journal of Environmental Research and Public Health, 18(3), 1111. doi:10.3390/ijerph18031111

Ortega, J., Villamizar, D. \& Ramos, Z. (2014). Toma de decisiones en árbitros de futbol: una mirada hacia la eficacia y eficiencia. Actividad física y desarrollo humano, 6(1). doi: doi.org/10.24054/ 
16927427.v1.n1.2014.1236

Padrón, A., Galán, I., Durbán, M., Gandarillas, A. \& Rodríguez-Artalejo, F. (2012). Confirmatory factor analysis of the General Health Questionnaire (GHQ12) in Spanish adolescents. Quality of Life Research, 21(7), 1291-1298. doi: doi.org/10.1007/ s11136-011-0038-x

Patiño, Ó. \& Cañadas, M. (2015). Análisis de la figura del árbitro deportivo y su intervención en el proceso de formación deportiva. Revista Pedagógica Adal, 18(30), 25-32.

Pedrosa, I. \& García, E. (2016). Síndrome de Burnout en Árbitros de Élite: La Liga de Fútbol Profesional Española (LFP) a Estudio. Revista Iberoamericana de Diagnóstico y Evaluación - eAvaliaçao Psicológica. RIDEP, 42(2), 59-68. doi: 10.21865/RIDEP42_59

Pedrosa, I. \& Garcia, E. (2015). Aspectos psicologicos en arbitros de elite: ¿afecta el salario a su bienestar emocional? Revista Psicología del Deporte, 24, 241-248.

Pena, M. \& Extremera, N. (2012). Inteligencia emocional percibida en el profesorado de Primaria y su relación con los niveles de burnout e ilusión por el trabajo (engagement): Perceived Emotional Intelligence in Primary School Teachers and Its Relationship with Levels of Burnout and Engagement. Ministerio de Educación. doi: doi.org/10.4438/1988592X-RE-2011-359-109

Prendas, J.L., Castro, W. \& Vargas, G.A. (2007). Identificación y comparación de síntomas de desgaste físico y mental en árbitros, entrenadores y educadores físicos. Pensar en movimiento Revista de Ciencias del Ejercicio y la Salud, 5(1), 55-69. doi: https: / / doi.org/10.15517/pensarmov.v5i1.361

Recio, D., Feliz, T. \& Elorza, J. (2021). La formación de árbitros y asistentes de futbol desde el enfoque flipped learning. Retos: Nuevas tendencias en Educación Física, Deporte y Recreación, 39, 794-804. doi: doi.org/ 10.47197/retos.v0i39.78222

Reigal, R., Videra, A., Parra, J. L. \& Juárez, R. (2015). Actividad físico deportiva, auto-concepto físico y bienestar psicológico en la adolescencia (Physical sports activity, physical self-concept and psychological wellbeing in adolescence). Retos: Nuevas tendencias en Educación Física, Deporte y Recreación, 22, 19-23. doi: doi.org/10.47197/retos.v0i22.34578

Rice, S., Purcell, R., De Silva, S., Mawren, D., McGorry, P. \& Parker, A. (2016). The mental health of elite athletes: A narrative systematic review. Sports Medicine, 46 (9), 1333-1353. doi:10.1007/s40279. 016-0492-2

Ringle, C., Hair, J., Hult, M. \& Sarstedt, M. (2017). A
Primer on Partial Least Squares Structural Equation Modeling (PLS-SEM). Thousand Oaks, CA: Sage publications.

Ringle, C., Hair, J., Risher, J. \& Sarstedt, M. (2019). When to use and how to report the results of PLSSEM, European Business Review, 31(1), 224. doi:10.1108/EBR-11-2018-0203

Rivera, Á., Segarra, P. \& Valverde, G. (2018). Síndrome de Burnout en docentes de instituciones de educación superior [Burnout syndrome in teachers of higher education institutions]. Archivos Venezolanos de Farmacología y Terapéutica, 37(2), 17-23. doi:10.35381/ r.k.v5i1.782

Rodríguez, J., Gómez, J. \& Álvarez, J. (2017). Papel del Psicólogo en el deporte. Roca. Revista Científico-Educacional de la provincia Granma, 10(4), 28-34.

Rodríguez, C., Correa, M., García, A. \& Bozal, R. (2018). Regulación emocional en jóvenes deportistas ante situaciones adversas en competición. doi:10.17060/ijodaep.2017.n1.v2.950

Ros, M., Moya, F. \& Garcés, D. (2013). Emotional intelligence and sport: current state of research. Cuadernos de Psicología del Deporte, 13(1), 105-112.

Rutkowska, K. \& Bergier, J. (2015). Psychological gender and emotional intelligence in youth female soccer players. Journal of human kinetics, 47(1), 285-291. doi: 10.1515/hukin-2015-0084

Ryff, C. D. \& Singer, B. (1998). The contours of positive human health. Psychological inquiry, 9(1), 1-28.

Sainz, M. (2010). Creatividad, personalidad y competencia socio-emocional en alumnos de alta habilidad versus no alta habilidad. Tesis doctoral: Universidad de Murcia

Salamero, M., Baranda, L., Mitjans, A., Bailles, E., Camara, M., Parramon, G., Gomez, E., Arteman, A. \& Padros, J. (2012). Estudio sobre la salud, estilos de vida y condicionantes academicos de los estudiantes de medicina de Cataluna. Fundacion Galatea: Barcelona.

Salamero, M., Baranda, L., Mitjans, A. \& Arteman, A. (2015). Estudio longitudinal sobre la salud, estilos de vida y condiciones de trabajo de los MIR. Fundación Galatea. Barcelona.

Salguero, J.M., Fernández-Berrocal, P., Ruiz-Aranda, D., Castillo, R. \& Palomera, R. (2011). Inteligencia emocional y ajuste psicosocial en la adolescencia: El papel de la percepción emocional. European Journal of Education and Psychology, 4(2), 143-152. doi:doi.org/10.30552/ejep.v4i2.71

Salom, M., Ponseti, F., Contestí, B., Salom, G., García, 
A. \& Núñez, A. (2020). Ansiedad competitiva y rendimiento en deportistas de vela (Competitive anxiety and performance in competing sailors). Retos: Nuevas tendencias en Educación Física, Deporte y Recreación, 39, 187-191. doi: doi.org/10.47197/ retos.v0i39.75356

Salovey, P. \& Mayer, J. (1990). Emotional intelligence. Imagination, cognition and personality, 9(3), 185-211

Samuel, R., Englerft, C., Zhang, Q. \& Basevitch, I. (2018). Hi ref, are you in control? Self-control, egodepletion, and performance in soccer referees. Psychology of Sport \& Exercise, 38, 167-175. doi:10.1016/j.psychsport.2018.06.009

Santos, T. R., Bicalho, C. C. F., Monteiro, A. C. P., Brandão, M. R. F. \& Mansur-Alves, M. (2021). Inventário de Burnout para Árbitros (BIR): propriedades psicométricas para árbitros brasileiros de futebol. Journal of Physical Education, 32. doi: doi.org/10.4025/jphyseduc.v32i1.3212

Sánchez, M. \& Breso, E. (2020). In Pursuit ofWork Performance: Testing the Contribution of Emotional Intelligence and Burnout. International Journal of Environmental Research and Public Health, 17(15), 5373. doi: 10.3390/ijerph17155373

Sánchez, M. P. \& Dresch, V. (2008). The 12-Item General Health Questionnaire (GHQ-12): Reliability, external validity and factor structure in the Spanish population. Psicothema, 20 (4), 839-843.

Sánchez, M., Megías, A., Gómez, R., Gutiérrez, M. \& Fernández, P. (2018). Relación entre la inteligencia emocional percibida y el comportamiento de riesgo en el ámbito de la salud. Escritos de Psicología Psychological Writings, 11(3),115-123. doi:10.5231/ psy.writ.2018.2712

Sánchez, M. L. M., Farrona, M. M., Guerrero, L. G., Unanue, J. G., Llorente, A. M., Mallén, J. A. C., \& Sánchez, J. S. (2021). Nivel de estudios y experiencia de las árbitras y árbitras asistentes de fútbol en España: Primera División Femenina. Cultura, ciencia y deporte, 16(50), 653-660. doi: doi.org/10.12800/ ccd.v16i50.1582

Selmi, W., Rebai, H., Chtara, M., Naceur, A. \& Sahli, S. (2018). Self-confidence and affect responses to short-term sprint interval training. Physiology. Behaviour. 188, 42-47. doi: doi.org/10.1016/ j.physbeh.2018.01.016

Servian, M., Vera, L., Britez, B. \& Rodriguez, P. (2019). Relacion de la salud mental y el sindrome de burnout en profesionales de enfermeria en un hospital re- gional. Nure investigacion.

Selya, A., Rose, J., Dierker, L., Hedeker, D. \& Mermelstein, R. (2012). A Practical Guide to Calculating Cohen's $\mathrm{f}(2)$, a Measure of Local Effect Size, from PROC MIXED. Frontiers in psychology, 3, 111. doi:10.3389/fpsyg. 2012.00111

Shami, R., Tare, M. \& Taran, H., (2017). Identifying the relationship among teacher's mental health and emotional intelligence and their burnout.

Independent Journal of Management \& Production, 8(1), 124143. doi: doi.org/10.14807/ijmp.v8i1.513

Sirin, Y. \& Dosyilmaz, E. (2017). Investigation of job satisfaction and burnout levels of Turkish super league football referees. Beden Editimi ve Spor Bilimleri Dergisi, 11(1), 87-96.

Soriano, G., Ramis, Y., Torregrossa, M. \& Cruz, J. (2018). Fuentes de estrés dentro y fuera del partido en árbitros de fútbol. Apunts. Educación física y deportes, 2(132), 22-31. doi: doi.org/10.5672/apunts.20140983.es.(2018/2).132.02

Spitz, J., Put, K., Wagemans, J., Williams, M. \& Helsen, W. (2018). The role of domain-generic and domainspecific perceptual-cognitive skills in association football referees. Psychology of Sport and Exercise, 34, 47-56. doi:10.1016/j.psychsport.2017.09.010

Weston, M., Castagna, C., Impellizzeri, F., Bizzini, M., Williams, A. \& Gregson, W. (2012). Science and medicine applied to soccer refereeing an update. Sport. Medicine, 42, 615-631. doi: doi.org/10.2165/ 11632360-000000000-00000

World, M. A. (2008). Declaracion de Helsinki de la Asociacion Medica Mundial. Principios eticos para las investigaciones medicas en seres humanos. In Anales del Sistema Sanitario de Navarra, 24(2), 209-212. doi: doi.org/10.23938/ASSN.0522

Zazo, R. \& Moreno, J. (2015). Hacia el bienestar psicológico en el ejercicio físico acuático. Revista Iberoamericana de Psicología del Ejercicio y el Deporte, 10(1), 3339. 